\section{Орални прояВи при пациенти с бъбречна тубулна ацugоза}

\section{Нина МусурлиеВа}

Kamegpa по Социална меgицина и общестВено зgраßе, Фаkултет по ОбщестВено зgраßе, Меgицински униВерситет - ПловguВ

\section{Резюме}

Бъбречна тубулна ациgоза (БТА) е заболяВане сВързано c натрупВане на пикочна киселина В организма, пораgu неспособност на бъбреците ga филтрuраm урината. Тя може ga бъge gВе форми - пърВична и Вторична (npugобита). Найчестата форма на пьрВична БТА при geцата е guсталната бъбречна тубулна auugoза. При нея се наб^Юgaßam хараkmерни орални промени - зъбите са с несъßършена емайлогенеза.

К^ючови gумu: бъбречни заболяВания, guстална бъбречна mубулна ациgоза, amelogenesis imperfecta

\section{Oral findings in patients with distal tubular acidosis}

\author{
Nina Musurlieva
}

Department of Social Medicine and Public Health, Faculty of Public Health, Medical University of Plovdiv

\section{Abstract}

Renal Tubular Acidosis (RTA) is a disease associated with the accumulation of uric acid in the body due to the kidney's inability to filter urine. It can be two forms - primary and secondary (acquired). The most common form of primary RTA among children is Distal Renal Tubular Acidosis. It causes characteristic oral changes - the teeth have imperfect amelogenesis.

Keywords: idney disease, distal kidney tubular acidosis, amelogenesis imperfecta

\section{Кореспонденция:}

Д-р Нина МусурлиеВа, gм

e-mail: nina_mussurlieva@abv.bg

\section{Correspondence:}

Dr. Nina Mussurlieva, DD, PhD

e-mail: nina_mussurlieva@abv.bg 


\section{Bъßеgение}

Бъбречна тубулна ацияоза (БТА) е заболяВане сВързано с натрупВане на пикочна киселина В организма, nopagu неспособност на бъбреците ga филтрират урината. Тя може ga бъge gВе форми - пърВична и Вторична (nрugобита). БТА може ga ce gъ^жи на реguца заболяВания kато guабетна kетоациgоза, лаkmатна auиgoза, хиnokсuя, хронична обструктивна белоgробна болест, цистиноза, gефицит на алgостерон, употребата на някои меgukаменти (спиронолактон, пентамияин, mриметоприм и gр.), тумори на бъбреците, тежки инфекции на урогениталния mpakm u gp. БТА може ga бъge gBa muna : Tun 1- Дистална тубулна ацияоза: тежка метаболитна auugoза nораgu неспособност на бъбреците ga повишаваm pH на урината nog 6. Усложненията Вk^ючВат резистентна Bum. Д остеомалация и бъбречна калциноза; Tun 2: Проксимална тубулна ацияоза: нарушение на обратната резорбция на бикарбонати (ациgоза, Вслеgствие загуба на бикарбонати). Клинично тя е по-лека В сраВнение с mun 1 (не се пояВяВа остеомалация и нефрокалциноза). Най-честата форма на пьрВична БТА при geцата е gucmanната бъбречна тубулна ацияоза [1].

Оралните прояВи при пациенти с ренални тубулни нарушения са описани $B$ световната митература $[3,4]$ и найчесто те се изразяВат В guспюазии на емайла (amelogenesis imperfecta). Целта на настоящото проучВане е ga ce преgстаВи кминичен случай на gентална алтерация при пациента с БТА.

\section{Mamepuan u memogu}

Kacae ce за 5 гоgишна пациентка, kоято е c gиагностицирана gистална бъбречна тубулна ацияоза. Анамнезата показа, че guагнозата е постаВена на 6 месечна Bъзраст. ПърВоначалните оплакВания са ненаggаВане на тегло, повръщане, хиперхлоремична ацияоза с повишено рH на урината, увеличен креатинин, нефрокалциноза. Диагнозата е постаßена слеg параклинични, серологични, ехографски и генетични изслеgВания. Детето посещаВа gенталния кабинет no nовоg профилактичен преглеg. При оралния преглеg се установи, че gememo е с Временно съзъбие. Зъбите са с намалена големина, абразирали с Жьлтокафяв цВят. Емайльт e mßъpg. По повърхностmа му се отkриват вgльбнатини, moчku u бразgu, Bъnpeku moßа негоßата цялост не е нарушена и не се оmkрuваm кариозни лезии (guаграма 1). Пациентkаma е с отлична орална хигиена. ГингиВата не показВа признаци на Възпаление и хиперпмазия.

\section{Обсъжgане}

Зъбните gисплазии са описани като орални прояВи nри различни бъбречни заболяВания (Fanconi syndrome, Bartter syndrome) особено тези, засягащи емайла [2]. Вpъзkата межgy нефрокалцинозата u geфеkтното формиране и минерализиране

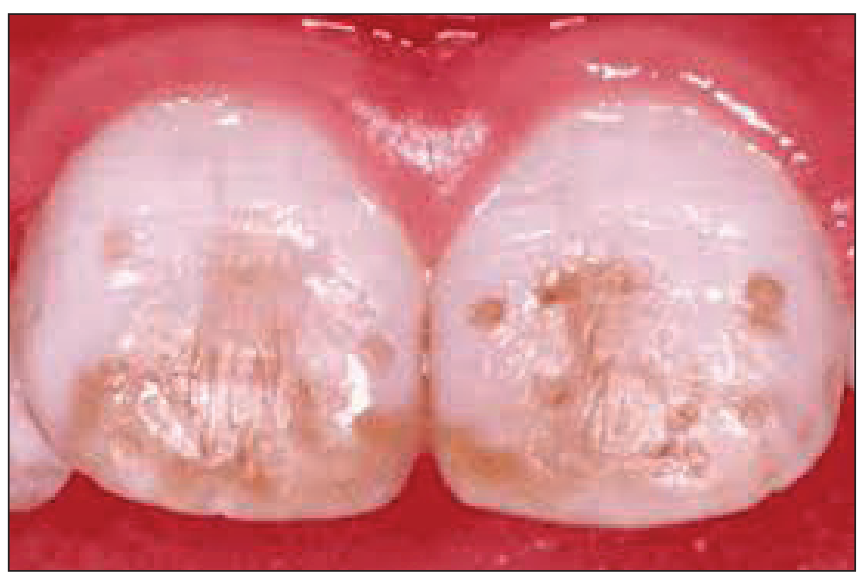

Диаграма 1. Точки, ВgлъбВания и бразgu с жълтокафяв цВят по повърхността на емайла

на емайла е gоказана $B$ няколkо проучВания [3,4]. Несъъършена емайлогенеза се наблюgaВа и В описания кминичен случай. Tyk guференциална guагноза се прави със зъбна фмуороза,употреба на mетрациклин, но снетата анамнеза показва наличие на общо заболяване, kakmo и липсваm gанни за сврьх прием на фмуориgu ики меguкаменти по Време на прееруптиВната фаза om развитието на зъбите. При такива пациенти е Важно ga се знае, че зъбите не се засягаm om kapuec във Bucoka степен, но той може ga се развие Вnослеgствие nораgu mова, че ВgльбВанията по емайла се яВяВат ретенционни места. Bторичната профилаkmuka е особено Важна. ИзползВат се локални флуорни апликации с разтвори, лакове, гелове, пасти u gp. Устната хигиена трябВа ga бъge стрukтно спазВана, mъй kamo хипоп^азиuте преgразполагат kьм натрупване на nмака. Обикновено при пациентите с бъбречни заболяВания се наблюgaßam пароgонтални промени, но В описания клиничен случай оралната хигиена е отлична, koemo е преgomßратило пароgонталното Възпаление и хиперплазията на гингиВата. Препоръчително е ga се извършъат регулярно gентални преглеgu (поне на 6 месеца), за gа се избегнат усложнения.

\section{Зак^ючение}

Необхоgими са gопьлнителни молекулярни изслеgВания за gоказВане на механизма на заражgане на зъбната алтерация при пациенти с БТА. Този клиничен случай още Веgнъж показ$\mathrm{Ba}$, че лечението на gеца с бъбречни заболяВания трябва gа е комплексно и мултuguсциплинарно. Тясната колаборация с gентални специалисти и ранното насочване за консултация c mяx ще goßege gо избягВане на орални усложнения и поgобряВане качестВото на жиВот.

\section{Бибмиография:}

1. Близнакова Д., РageBa Т., Bemkoßа М. Многолиkomo мице на нефрокалцинозата B gemcka Възраст. ИзВестия на съюза на учените - Варна 2'2013 / TOM XVIII; cmp.32-6.

2. MameeВa Хр. ПроnegeBmuka u nрофuлаkmuka B gemckama стоматология. Меguцина и физкултура. София 1995. 
3. Ferreira S., Silva A., Pereira P. et al. Dental findings in patients with renal tubular acidosis. Journal of pediatric dentistry 2016; 4:77-9.
4. Ravi P., Ekambaranath T., Arasi S. et al. Distal renal tubular acidosis and amelogenesis imperfect. A rare association. Indian J Nephrol 2013; 23:452-5. 